\title{
SIDS UNEXPECTED/UNEXPLAINED/UNDETERMINED/UNCLEAR IS INCORRECT
}

\author{
Narayana Rao Vaddi ${ }^{1}$
}

${ }_{1}^{1}$ Professor and HOD, Department of Forensic Medicine, Maharaja Institute of Medical Sciences, Nellimarla.

\section{ABSTRACT}

\section{BACKGROUND}

The biggest unsolved medical mystery today is the worldwide sudden infant deaths. Due to lack of care, skill, knowledge and wilful negligence of doctors they are not able to diagnose the cause of sudden infant deaths. Globally, SIDS death crosses 22,000 every year. SID- Sudden Infant Death, age $<1$ year infant.

SUD- Sudden Unexpected Death, age $<1$ year infant.

SIDS- Sudden Infant Death Syndrome, age $<1$ year infant.

SUID- Sudden Unexplained Infant Death, age $<1$ year infant.

SSIDS- Simultaneous Sudden Infant Death Syndrome, age $<1$ year infant.

Main causes of death are due to thymus and lymph node defects and feeding mother's bad habits, and also due to "A to Z" causes given below. A child requires care and protection.

My aim is to make at least some feeding mothers to change their attitude. As per Biblical times, in Old Testament Solomon says that "this woman's child died in the night because she overlaid it" - "Holy Bible Old Testament, 1 ${ }^{\text {st }}$ Kings 3:19 "SIDS Unexpected/Unexplained/Undetermined is incorrect.

\section{KEYWORDS}

Thymus, Soft Bedding, Suffocation, Lymph Nodes, Mother's Drug Abuse, Sleep Position.

HOW TO CITE THIS ARTICLE: Vaddi NR. SIDS unexpected/unexplained/undetermined/unclear is incorrect. J. Evolution Med. Dent. Sci. 2017;6(61):4507-4511, DOI: 10.14260/Jemds/2017/974

\section{BACKGROUND}

Globally, every year millions of SIDS also referred to as "cot death" is a thing within one year age of infants.(1) It is the unexpected death of an apparently healthy infant during sleep. Every death must have a definite cause of death. Doctor's opinion of the cause of death - "respiratory-cardiac failure" is incorrect, it must have a definite cause of death. What the causes are or how to prevent is advocated to the parents. In India, most of the deaths are not reported due to lack of knowledge of doctors. According to the Centres for Diseases Control (CDC), overall rate of SIDS coming down is incorrect. It is important to take precautions to avoid this sudden death in otherwise a healthy baby. The study was done on various parameters associated; some of these little aspects should be taken care of to reduce the risk of SIDS deaths to regulate the human behaviour in present days. Hence, there should be a direct study of the relationship between parents and children to control SIDS.

\section{MATERIALS AND METHODS}

- In 1826- Alexander Hood noted 5 cases of SID associated with enlarged thymus.

- In 1830s- John Heinrich Kopp designated it as thymus asthma, which caused mechanical pressure on the trachea or associated nerves and vessels.

- In 1860- Rudolph Virchow supported Kopp's theory of same pathology.

Financial or Other, Competing Interest: None.

Submission 06-04-2017, Peer Review 12-05-2017,

Acceptance 18-05-2017, Published 31-07-2017.

Corresponding Author:

Dr. Narayana Rao Vaddi,

Professor and HOD,

Department of Forensic Medicine,

Maharaja Institute of Medical Sciences,

Nellimarla-535217.

E-mail: forensic.vaddi@gmail.com

DOI: $10.14260 /$ jemds $/ 2017 / 974$
- In 1888- Paul Grawits' several cases of SID, enlarged thymus.

- In 1889- Arnold Paltauf haemorrhages in drowning.

- $20^{\text {th }}$ Century- 127 cases of SID, unusual enlarged lymph nodes.

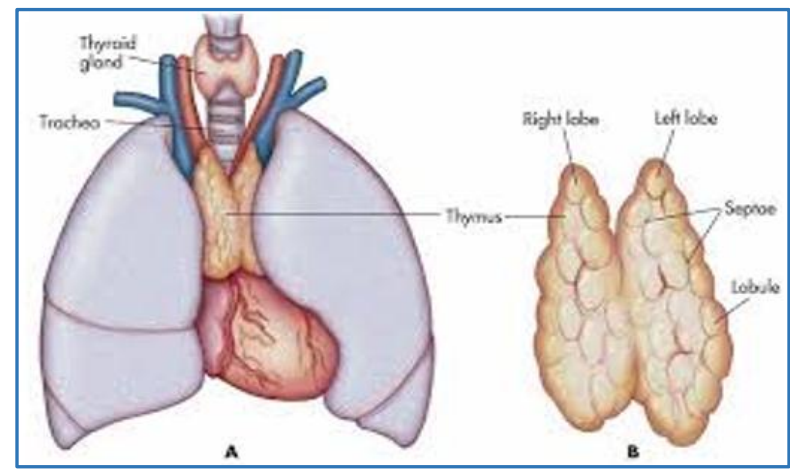

Figure 1. Thymus Defect

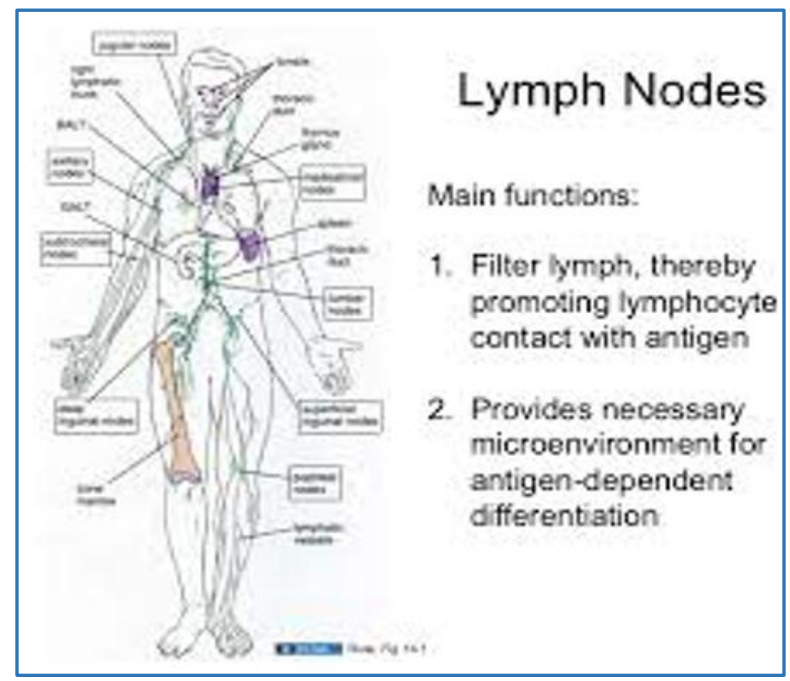

Figure 2. Lymph Nodes 


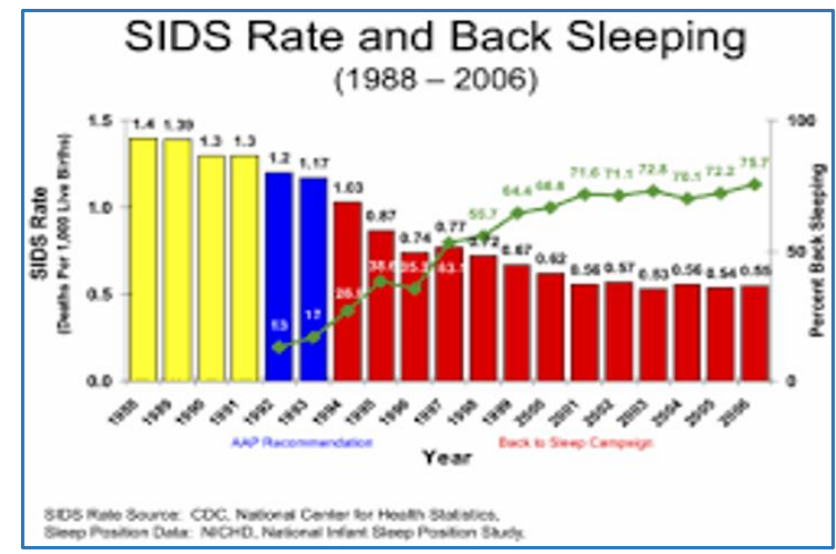

Figure 3. SIDS Rate and Face Down Position

\section{A - Z causes for Sudden Infant Deaths-}

A- Allergy due to cow's milk, Alcoholic mothers, Adrenal deficiency, Anaemia.(2)

B- Biotin deficiency, Brain stem abnormality, Bottle feeding, Bedding, Botulinism, Battered baby syndrome - pre-planned.(3)

C- Calcium deficiency, Common cold, Charging cell phone wires on bed may cause strangulation,(4) Co-sleeping of parents with infant, Cocaine addiction of mother, Congenital heart diseases.

D- Defect in heart,(4) Diphtheria, Dry drowning, Devices, Down's syndrome, (2) Drugs.

E- Enlarged thyroid, Enzymes deficiency, Environment at home, (5) Enlarged lymph nodes.

F- Fault neck position, Feeding in prone position, FaceDown position.

G- Gadgets near to cot/crib, Genetic disorder.

H- Heat stresses, Hepatic-B, Heart rate increase, Home mites, Hypothermia, Hyperthermia, Heart problems.

I- Infections with Staphylococcus, E. coli, Viral, etc., Insects bites.

J- Jaundice, Jacksonian epilepsy, Jugular pressure with side pillow.

K- Kwashiorkor, Kernicterus, Ketonuria, Klebsiella, Knots.

L- Laryngeal(6) spasm, Long Q-T interval syndrome, Laptops near to bed,(7) Laryngitis.

M- Magnesium deficiency, Meningitis, Mobile phones, Milk in bronchioles, Metabolic disorders

N- Neonatal jaundice, Nasal oedema, Nasal obstruction.

0- Over crying, Obstructive airway, Oedema of feet and hands, Overlaid it.(1)

P- Prone position sleep, Pertussis, Parathyroid hormone deficiency, Peptic ulcer, Poor family, Peritonitis, Pneumonitis, Pleurisy.

Q- Q-fever, Quadriplegia sudden, Q-T interval abnormality.

R- Respiratory infections, Renal failure, Renal stones, Retention of urine.

S- Sodium overload indeed, Sleep apnoea, Spinal haemorrhage, Suffocation with clothes or pillows, Smoking in infant room, Soft bedding, Shaken baby syndrome,(2) Short time period between pregnancies,(6) Sharing of beds, Sleep reduced apnoea, Spider bites.

T- Tetanus, Twins, Triplets, Thyme asthma, Toxic matters, TB meningitis, Tracheal bronchitis, Transient cerebral anoxia, Tobacco smoking,(6) Teenage girl's child birth.

U- Upper respiratory infection, Uraemia, Ulcerative colitis, Urine retention.

V- Vitamin deficiency, Vomited milk goes to lungs, Vaccinated improperly.

W- Wears, Weight loss, Water-borne disease, Water intoxication, Whooping cough, Wilson disease, Weird, Winter season, Whiplash injury.

X- Xanthelasma-xenogenetic.

Y- Yellow fever, Yawning mouth fixed for long time.

Z- Zinc deficiency, Zollinger syndrome (Peptic ulcer).

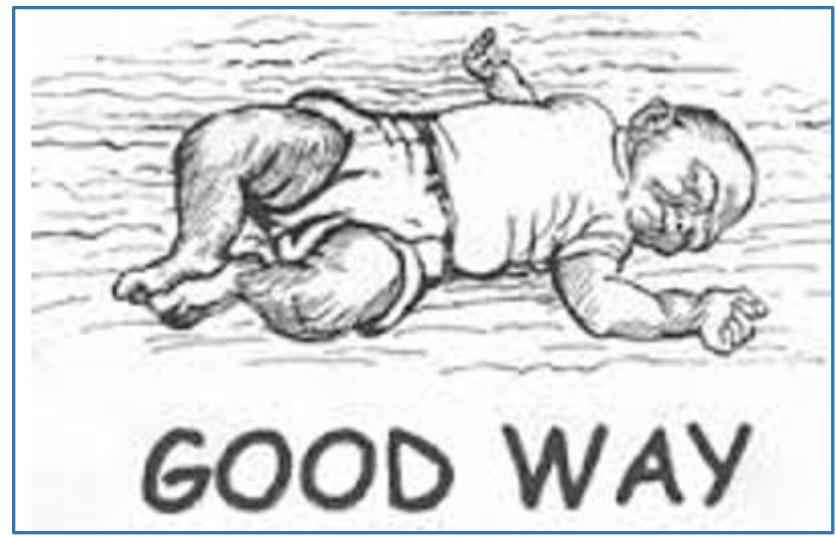

Figure 4. Good Way

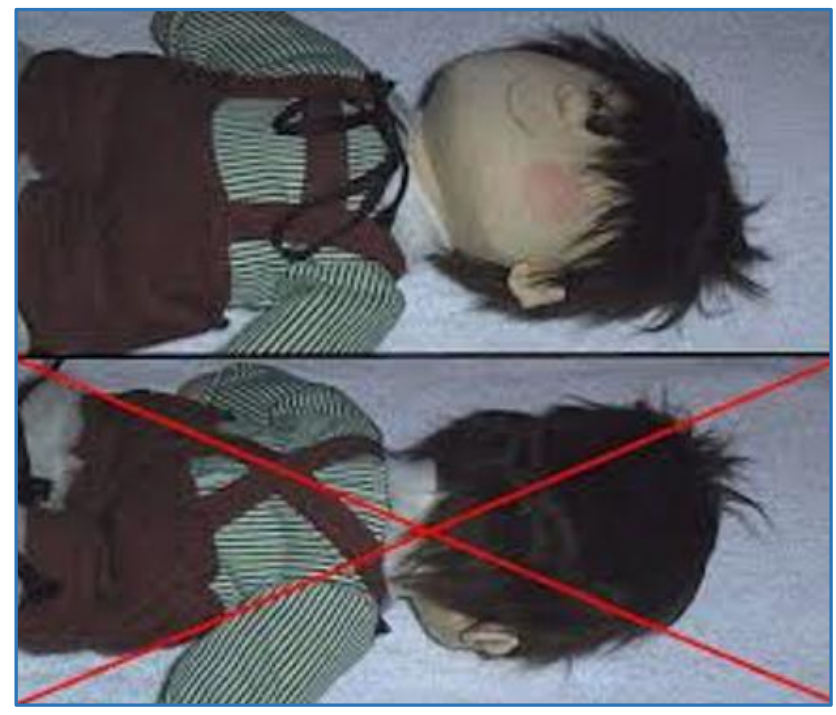

Figure 5. Correct and Wrong Position of Sleeping

\section{OBSERVATION AND DISCUSSION}

Rates vary significantly by population; in Hong Kong0.05/1000, in America- 6.7/1000.

In India, SIDS is $0.84 / 1000$ live births. According to John Kathwinker, Chairman of the Lanterns for Disease Control, prevention decreased SIDS. A lot of us is benefitted. In 2013, there were persistent disparities in SIDS death in racial and ethnic groups. In US in 2009, 2013 Rate of SIDS. Asian/Pacific Islands- 119.2. American Indians/Alaska- 24\%.

The rate per 1000 births varies in different areas(8) Central America 0.20; Asia 0.28; Mexico 0.24; Puerto Rican 0.53; Whites 0.51; African-American, 1.08; America-India 1.24. 
How to Control and Prevent Sudden Infant Deaths (SIDS)

1. Soft bedding is dangerous to infants, i.e. In soft bed vomited milk goes to lungs, may cause suffocation, so avoid soft beds.(6)

2. Home- avoid smoking at home.

3. Sharp objects to be kept away from child.

4. Avoid commercial devices.

5. Mobile phones to be kept away from infants. (6)

6. Laptops to be kept away from infants.

7. Gadgets to be kept away from infants.

8. Do not keep the phones for charging on infant's bed.

9. Low birth weight, a preterm baby needs extra care, handle carefully.

10. Do not feed in sleep position, only on sitting position.

11. After every feed must hold up for burp, as it ensures that the stomach has cleared itself of extra air.

12. Baby is small and their reflexes are still developing, hence till the time the brain realises the danger it is too late, must be taken care of, otherwise it is fatal.

13. Regular vaccination for preventive measures.

14. Maternal education regarding baby care.

15. Improve social, economical and cultural factors.

16. Putting infant to bed on their side.

17. Teenage girls should not give birth.

18. (CDC) Improve the centres for disease prevention proposed. $(9,10)$

19. Face down posture of sleeping is dangerous.

20. Bed making, no loose clothes, cot/crib.

21. Breast-feeding and immunisation prevents SIDS.(11,12)

22. Sufficient environmental air, it prevents suffocation (use fans).

23. Having siblings in the same crib may cause SIDS.

24. Proper prenatal care.

25. Working mothers busy in office should handover babies to caretakers and should always watch through CC cameras connected to their cell phone.

26. Computer operating mothers are not to forget their child.

27. Housewives busy in the kitchen are not to forget their child.

28. Baby's sleep bags or sleep slats for baby's protection should be at least 2 inches apart.(12)

29. Maintaining baby's temperature reduces the SIDS.

30. Low birth weight baby's clothes for properly covering the baby.

31. Proper ventilation in the baby's room.

32. Free atmosphere.

33. Optimum temperature.

34. Firm and tight-fitting mattress.

35. Crib height at least 2 feet.

36. Do not cover the baby with blankets.

37. Do not medicate an infant without consulting a paediatrician.

38. Discourage bottle feeding.

39. Parents, caregiver of an infant must not sleep along with baby.

40. A separate properly designed crib must be used for the baby.

41. Genetic test to exclude genetic disorder.

42. Biochemical test to check the levels of cytotoxicity.

43. Feeding mothers should not take any sedative drugs, alcohol or smoking.(7)

44. Feeding mothers should avail the maternity leave.

45 . Timely sleeping of the baby.
46. Awareness of NICHD- National Institute of Child Health Human Devolvement "save to sleep" campaign.

47. Mother must be in a sitting posture while feeding the baby. 48. Do not put any mosquito repellents like All-out near the baby's cot.

49. Have regular check-ups, know the side effects of prescribed drugs. ${ }^{(6)}$

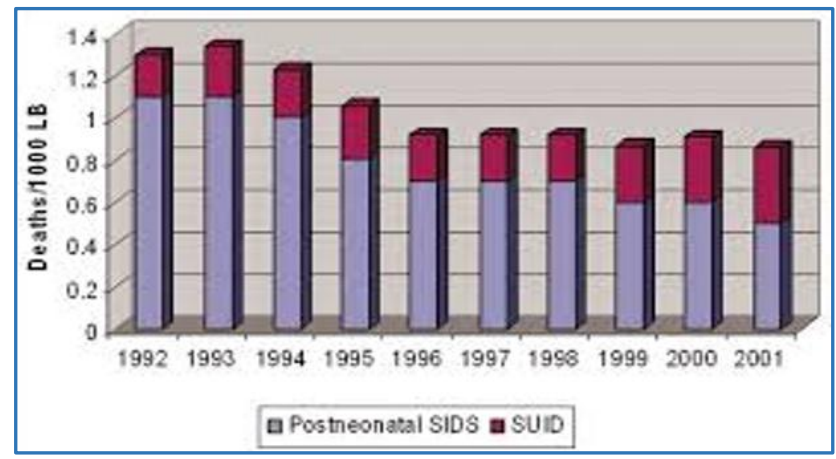

Table No. 1

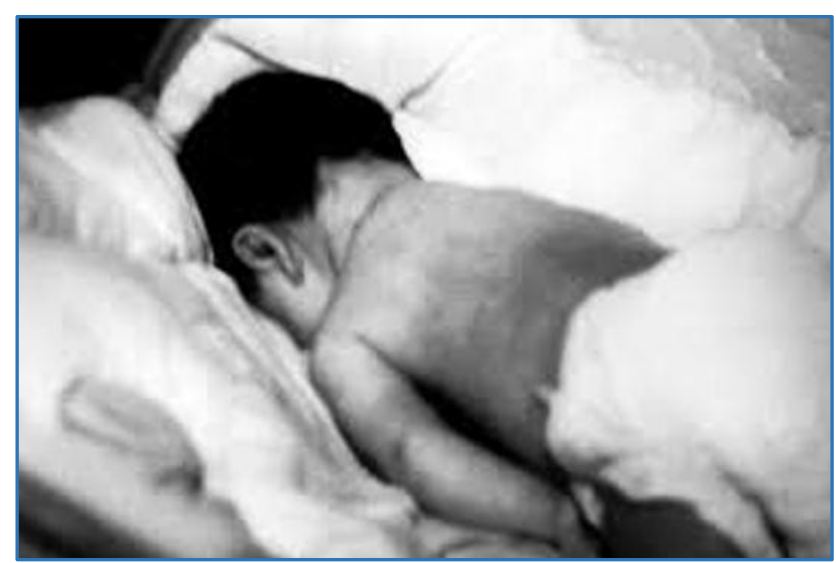

Figure 6. Face Down Position

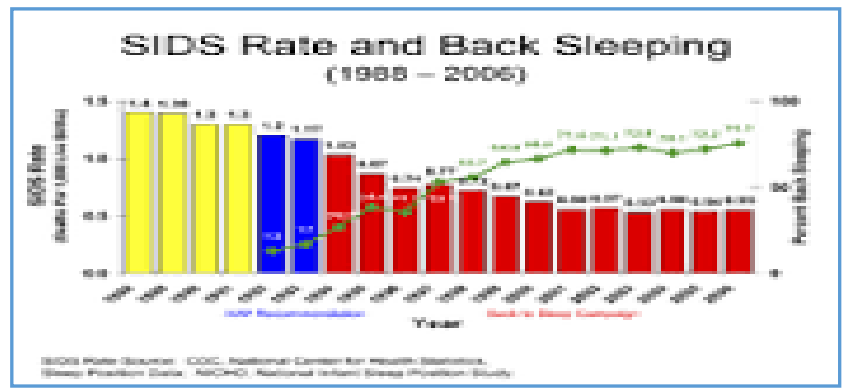

Table No. 2 (11)

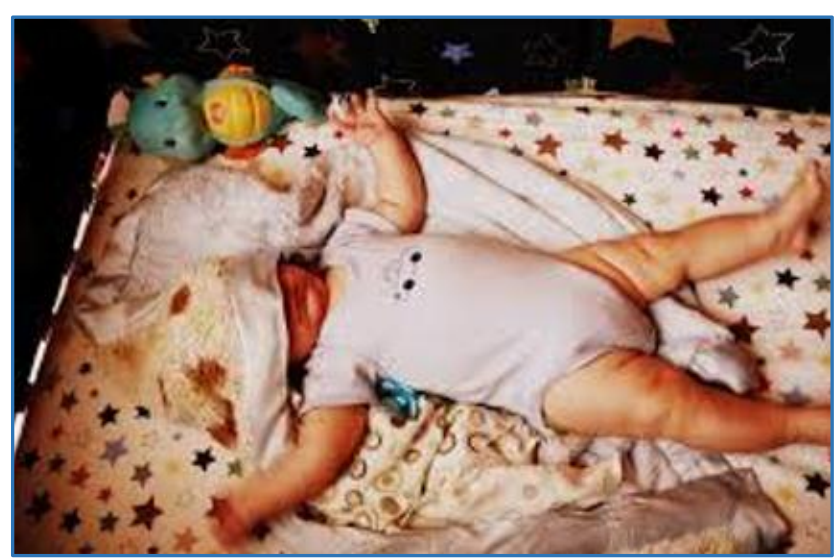

Figure 7. Clothes on the Face 


\section{Death Rate of SIDS(13)}

\section{Developed Countries 1 in 1000 Live Infants}

Globally, no. of SIDS death was reduced from 22000 (1990) to 15000 (2013) in USA.

In USA, SIDS was the $3^{\text {rd }}$ most leading cause of death in infants. $90 \%$ infant deaths $<6$ months.

In 2 - 4 months, more common in boys than girls.(14)

\section{COMMONLY AFFECTED AGE GROUPS FROM SIDS(15)}

Below 1 month, 10.8\%; 1 - 3 months, 27.05\%; 3 - 7 months, 40.5\%; 7 - 12 months, $21.6 \%$

Rate per 1000 births varies in different areas of world(16) Central America and South America 0.20; Asian and Pacific Islands 0.28; Mexican 0.28; Puerto Ricans 0.58; Whites 0.51; Africans 1.08; Indians 1.24.

\section{Medico-Legal(5)}

One SID- Tragedy;

Two SIDS- Suspicious;

Three SIDS- Murder.

Until the process otherwise failed in the court, court considered natural phenomena.

\section{Unestimated(14)}

1984- 40,000; 1990- 30,000; 1992- 4895; 2004- 2247; 1984 2004 decreased to $80 \%-50 \% ; 2010-22,00$.

\section{Autopsy Findings Usually(17)}

1. An autopsy (by an experienced paediatric pathologist, if possible).

2. Investigation of the death scene and circumstances of the death.

3. Exploration of the medical history of the infant and family.(6)

4. Thymus is the usual cause of SIDS death,(18) hands clenched.

5. Lymph nodes enlarged, milk-stained froth, inflammatory changes in the respiratory tract.

6. Blood-stained froth in mouth.(4)

7. Petechial haemorrhage in viscera or large ecchymosis on the epicardial surface of the heart.(3)

8. Congenital heart disease in some cases.(3)

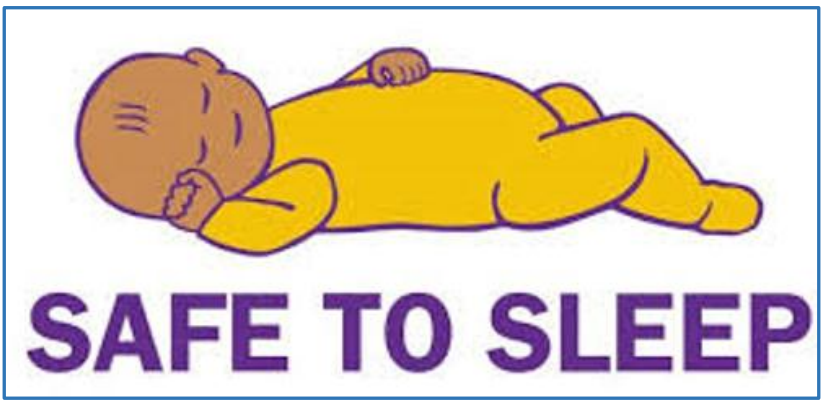

\section{CONCLUSION}

\section{Social Forensic Message ${ }^{(19)}$}

Give special care to your child in rainy and winter seasons due to peak incidents during nights. Child requires care and protection, not exploitation. Always advocate consoling for feeding mothers.(19) After these control measures, at least some feeding mothers should change their attitudes. Many doctors giving death certificate for SIDS as cardiorespiratory failure is a wrong opinion. ${ }^{(20)}$ There must be a definite cause of death. SIDS, unexpected/unexplained/undetermined is incorrect.

\section{REFERENCES}

[1] L'Hoir MP, Engelberts AC, van Well GT, et al. Risk and preventive factors for cot death in the Netherlands, a low-incidence country. Eur J Pediatr 1998;157(8):6818.

[2] Bandar R. Principles of forensic medicine of toxicology. $1^{\text {st }}$ edn. Jaypee brother medical publishes (p) LTD new Delhi- pancake city London 2011.

[3] Adelson L. Lawrence avenge, Springfield Illinois USA printed in the United States of America. Published and distributed throughout the world by Charles Thomas published 1974:301-327.

[4] Pillay VV. Text book of forensic medicine of toxicology. $17^{\text {th }}$ edn. Pares medical publishes Hyderabad- New Delhi 2016.

[5] Narayanareddy KS. Medical jurisprudence \& toxicology. $1^{\text {st }}$ edn. ALT publications Hyderabad 2000.

[6] Sighal SK. Sighal's toxicology at a glance. $2^{\text {nd }}$ edn. The National Book Depot, Mumbai 2004:12-293.

[7] Ignatus PC. Forensic medicine of toxicology. $2^{\text {nd }}$ edn. Published by Letter Wave Books 2016:p 353.

[8] Sharma BR. Sudden infant death syndrome: a subject of medicolegal research. The American Journal of Forensic Medicine and Pathology 2007;28(1):69-72.

[9] Powers DA, Song S. Absolute change in cause-specific infant mortality for blacks and whites in the US: 19832002. Tion Research and Policy Review 2009; 28(6):817-51.

[10] Agarwal S. Legal medicine manual. $1^{\text {st }}$ edn. Jaypee brothers Medical Publishers (P) LTD. New Delhi 2008:p 190.

[11] Murty OP. Operational guidelines for post-mortem examinations and auditing. $1^{\text {st }}$ edn. CBS Publishers \& Distributors Pvt Ltd New Delhi 2016:p 139.

[12] Poets CF, Samuels MP, Wardrop CA, et al. Reduced haemoglobin levels in infants presenting with apparent life-threatening events-a retrospective investigation. Acta Paediatr 1992;81(4):319-21.

[13] Smith MG, Liu J, Helms KH, et al. Racial differences in trends and predictors of infant sleep positioning in South Carolina, 1996-2007. Maternal and Child Health Journal 2012;16(1):72-82.

[14] Lozano R, Naghavi M, Foreman K, et al. Global and regional mortality from 235 causes of death for 20 age groups in 1990 and 2010: a systematic analysis for the global burden of disease study 2010. Lancet 2012; 380(9859):2095-128.

[15] Mant AK. Taylor's principles and practice of medical jurisprudence. $13^{\text {th }}$ edn. Published by Churchill Livingstone, New Delhi 2000:p 347.

[16] Prasad BD. Essential of forensic medicine \& toxicology. $1^{\text {st }}$ edn. AITBS Publications India, Delhi 2017:p 221. 
[17] Sighal SK. Singhal's The Doctor \& Law. $1^{\text {st }}$ edn. The National Book Depot, Mumbai 1999:p 129.

[18] Agrawal A. Forensic medicine of toxicology for MBBS. $1^{\text {st }}$ edn. Avichal publishing company New Delhi 2016.
[19] Sullivan FM, Barlow SM. Review of risk factors for sudden infant death syndrome. Paediatric Perinatal Epidemiology 2001;15(2):144-200.

[20] Moon RY, Horne RS, Hauck FR. Sudden infant death syndrome. Lancet 2007;370(9598):1578-87. 